January 2006

\title{
Fall Fertilization Timing Effects on Nitrate Leaching and Turfgrass Color and Growth
}

Salvatore Mangiafico

University of Connecticut, srman@juno.com

Karl Guillard

University of Connecticut Department of Plant Science, karl.guillard@uconn.edu

Follow this and additional works at: https://opencommons.uconn.edu/plsc_articles

\section{Recommended Citation}

Mangiafico, Salvatore and Guillard, Karl, "Fall Fertilization Timing Effects on Nitrate Leaching and Turfgrass Color and Growth" (2006). Plant Science Articles. 14.

https://opencommons.uconn.edu/plsc_articles/14 


\title{
Fall Fertilization Timing Effects on Nitrate Leaching and Turfgrass Color and Growth
}

\author{
Salvatore S. Mangiafico and Karl Guillard*
}

\begin{abstract}
Fall season fertilization is a widely recommended practice for turfgrass. Fertilizer applied in the fall, however, may be subject to substantial leaching losses. A field study was conducted in Connecticut to determine the timing effects of fall fertilization on nitrate $\mathrm{N}$ $\left(\mathrm{NO}_{3}-\mathrm{N}\right)$ leaching, turf color, shoot density, and root mass of a $90 \%$ Kentucky bluegrass (Poa pratensis L.), 10\% creeping red fescue (Festuca rubra L.) lawn. Treatments consisted of the date of fall fertilization: 15 September, 15 October, 15 November, 15 December, or control which received no fall fertilizer. Percolate water was collected weekly with soil monolith lysimeters. Mean $\log _{10} \mathrm{NO}_{3}-\mathrm{N}$ concentrations in percolate were higher for fall fertilized treatments than for the control. Mean $\mathrm{NO}_{3}-\mathrm{N}$ mass collected in percolate water was linearly related to the date of fertilizer application, with higher $\mathrm{NO}_{3}-\mathrm{N}$ loss for later application dates. Applying fall fertilizer improved turf color and density but there were no differences in color or density among applications made between 15 October and 15 December. These findings suggest that the current recommendation of applying $\mathbf{N}$ in mid- to late November in southern New England may not be compatible with water quality goals.
\end{abstract}

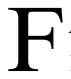
ALL FERTILIZATION is a widely recommended practice for cool-season turfgrass in southern New England and elsewhere in temperate climates. Reported agronomic benefits of fall fertilization include improved color in the spring (Powell et al., 1967b; Wilkinson and Duff, 1972; Wehner et al., 1988; Wehner and Haley, 1993), increased root mass in either the winter or spring (Hanson and Juska, 1961; Powell et al., 1967a), and decreased carbohydrate depletion in the winter (Powell et al., 1967b). To achieve the full agronomic benefit of fall fertilization and avoid a flush of top growth in the fall, it has been suggested that fertilizer should be applied late in the season, after most top growth has ceased (Hanson and Juska, 1961; Wilkinson and Duff, 1972; Wehner and Haley, 1993). Determination of an application date of fall fertilizer for optimal agronomic benefit is difficult, however, because previous studies were performed under different climatic and maintenance conditions and with different species. Conclusions about specific fertilization dates would not be applicable to distinctly different climates. Determination of an application date is difficult also because few studies directly compared fall fertilizer application on different dates (Wilkinson and Duff, 1972; Wehner et al., 1988; Wehner and Haley, 1993). In general, these three studies concluded that turf fertilized in November or later developed better spring color than

Department of Plant Science, Unit 4067, University of Connecticut, 1376 Storrs Road, Storrs, CT 06269-4067. Received 17 Feb. 2005. *Corresponding author (karl.guillard@uconn.edu).

Published in J. Environ. Qual. 35:163-171 (2006).

Technical Reports: Vadose Zone Processes and Chemical Transport doi:10.2134/jeq2005.0061

(c) ASA, CSSA, SSSA

677 S. Segoe Rd., Madison, WI 53711 USA turf fertilized earlier in the fall, but this conclusion was not unequivocal in all cases.

There is concern about $\mathrm{NO}_{3}-\mathrm{N}$ losses from managed turf areas due to the negative environmental and human heath effects of $\mathrm{NO}_{3}-\mathrm{N}$ in surface and ground waters. The date of fertilizer application may affect the potential for significant $\mathrm{NO}_{3}-\mathrm{N}$ leaching. Because the late fall and winter are characterized by low temperatures, high precipitation, low evapotranspiration, and low plant uptake, fertilizer applied to turf in the fall may be subject to leaching losses (Petrovic, 1990). Supporting this, Miltner et al. (2001) found increased soil $\mathrm{NO}_{3}-\mathrm{N}$ concentrations in the fall under an intense turf fertilization regime, suggesting the possibility of increased leaching potential in the fall or winter. Similarly, Guillard and Kopp (2004) found greater $\mathrm{NO}_{3}-\mathrm{N}$ leaching losses from turfgrass when potential evapotranspiration was low. Some studies concerning $\mathrm{N}$ leaching from turfgrass systems have reported increased $\mathrm{N}$ concentration or $\mathrm{N}$ mass loss in percolate water during the fall or winter (Petrovic et al., 1986; Geron et al., 1993; Liu et al., 1997; Guillard and Kopp, 2004). Geron et al. (1993), in one year of their study, found greater winter percolate water $\mathrm{NO}_{3}-\mathrm{N}$ concentrations from a fertilization program including a November application than from a program without one. Similarly, Miltner et al. (1996) found higher $\mathrm{NO}_{3}-\mathrm{N}$ concentrations in leachate throughout their study and a greater recovery of labeled ${ }^{15} \mathrm{~N}$ in leachate from a fertilization program including a November application.

Recommended dates for fall application of fertilizer must take into consideration both agronomic benefits and potential leaching losses, as well as the climate at the application site. We are aware of only one study that has been conducted in southern New England comparing turf quality among fall fertilization dates (Wilkinson and Duff, 1972), and none comparing $\mathrm{N}$ leaching losses among fall fertilization dates. Therefore, this study was conducted to investigate the timing effects of fall fertilization on both leaching losses and turfgrass color, density, root mass, and clipping yield for a turf stand in southern New England under a home lawn maintenance regime.

\section{MATERIALS AND METHODS}

\section{Experimental Site and Lysimeters}

A field experiment was conducted at the University of Connecticut in Storrs, CT, USA, from 7 Aug. 2000 to 15 May 2003. Soil monolith lysimeters used in the study had been installed in 1995 for use in a leaching study involving nursery container crops (Colangelo and Brand, 2001). The lysimeters consisted of high-density polyethylene barrels $56 \mathrm{~cm}$ in diameter and $85 \mathrm{~cm}$ deep. The barrels were installed vertically in the soil with the tops open (Fig. 1). The bottom of the barrels were closed but fitted with polyvinyl chloride fittings and $1.3-\mathrm{cm}-$ diameter polyethylene tubes leading to 19-L schedule 40 polyvinyl chloride pipes. These pipes were capped at both ends and 


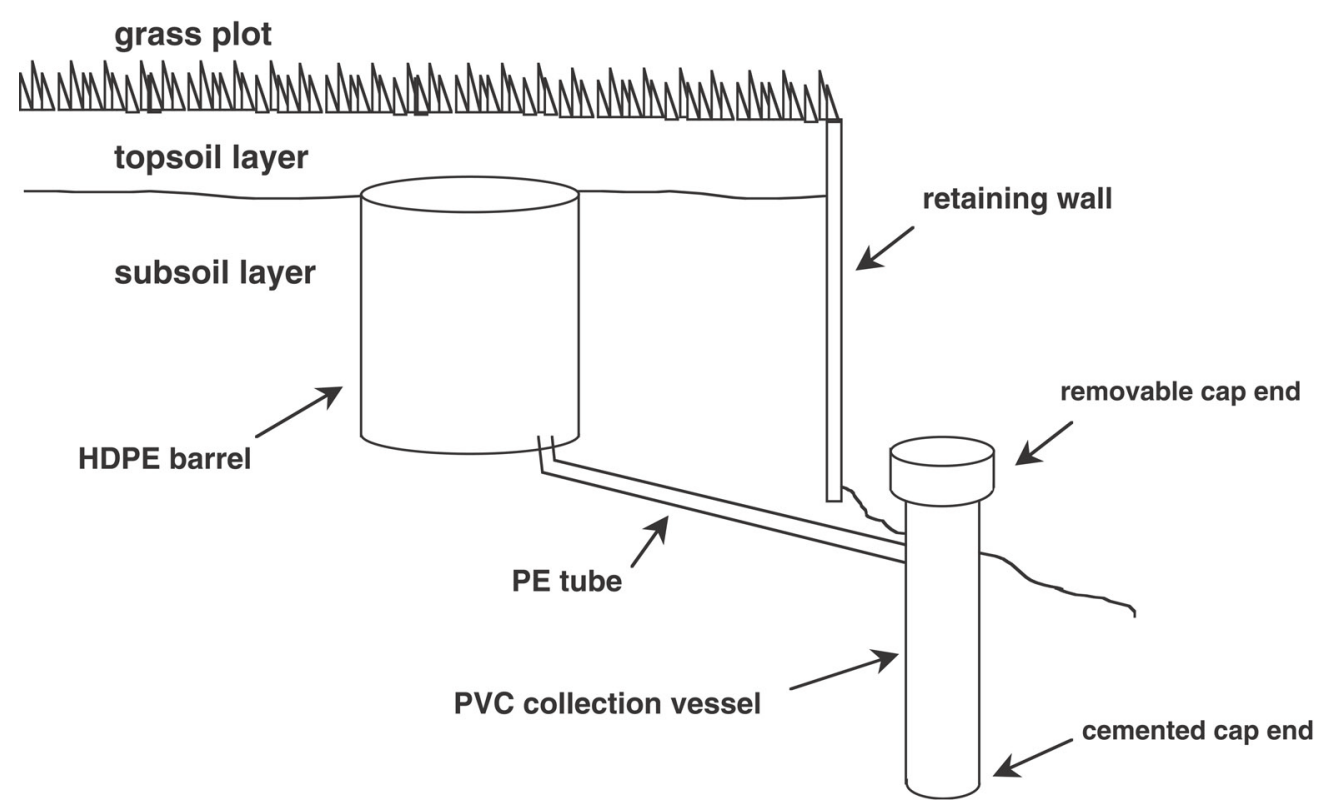

Fig. 1. Side view schematic of soil monolith lysimeter and collection vessel.

installed vertically in the soil about $2 \mathrm{~m}$ away from the barrels for use as collection vessels. The collection vessels were vented with a small hole with a glass wool screen, and removing the top cap allowed access to the contents of the collection vessels. The barrels were installed in the soil and pitched so that all water collected in the barrel would drain through the tube and into the collection vessel. The bottom of each lysimeter was lined with woven fiberglass fabric to prevent soil from moving into the collection vessel. The barrels were filled with a screened soil having a loamy sand texture, a $\mathrm{pH}$ of $5.7,14 \mathrm{~g} \mathrm{~kg}^{-1}$ organic matter by dry combustion (Ball, 1964), and $8.0 \mathrm{mg} \mathrm{kg}^{-1} \mathrm{NO}_{3}-\mathrm{N}$ by $2 \mathrm{M} \mathrm{KCl}$ extraction (Mulvaney, 1996). In the summer of 2000 , existing vegetation on the site was killed with glyphosate $[N$ (phosphonomethyl)glycine] and tilled into the soil. The entire site was topped with $20 \mathrm{~cm}$ of commercial topsoil to mimic the soil profile of a newly constructed home lawn. The tops of the lysimeter barrels were approximately at the bottom of this topsoil layer. The topsoil had a loamy sand texture, a $\mathrm{pH}$ of 5.9, $19 \mathrm{~g} \mathrm{~kg}^{-1}$ organic matter, and $9.4 \mathrm{mg} \mathrm{kg}^{-1} \mathrm{NO}_{3}-\mathrm{N}$. The site was then sodded with $90 \%$ Kentucky bluegrass ('Midnight', 'Adelphi', 'America', and 'Touchdown') and 10\% 'Cindy' creeping red fescue. Collection vessels were washed with hydrochloric acid and rinsed with deionized water before the commencement of monitoring. Fourteen turf plots, measuring 1.4 by $2.4 \mathrm{~m}$ each, were arranged with one lysimeter per plot.

\section{Experimental Design, Treatments, and Management}

Treatments consisted of the date of fall fertilizer application. Treatment plots received $49 \mathrm{~kg} \mathrm{~N}^{-1}$ of a 10-7-17 (N-P-K) commercial lawn fertilizer (Greenview Wintergreen; Lebanon Seaboard Corp., Lebanon, PA), applied by hand, on one of the following dates: 15 September, 15 October, 15 November, 15 December. This fertilizer had $60 \%$ of $\mathrm{N}_{\text {as }} \mathrm{NH}_{4}{ }^{+}$and $40 \%$ as urea. On no fertilizer application date was there snow or frozen soil. Each treatment was replicated three times in a completely random design. The two control plots received no fall fertilizer. All plots each received $49 \mathrm{~kg} \mathrm{~N} \mathrm{ha}^{-1}$ on each of two applications, one in early May and one in late June, of a 30-1.7-3.2 commercial lawn fertilizer (Greenview Greenpower; Lebanon
Seaboard Corp.). This fertilizer had $9 \%$ of $\mathrm{N}$ as $\mathrm{NH}_{4}{ }^{+}, 74 \%$ as urea, and $17 \%$ as water-insoluble $\mathrm{N}$. This fertilization plan resulted in each fall fertilized plot receiving $147 \mathrm{~kg} \mathrm{~N} \mathrm{ha}^{-1} \mathrm{yr}^{-1}$, and each control plot receiving $98 \mathrm{~kg} \mathrm{~N}^{-1} \mathrm{yr}^{-1}$. Plots that received no fall fertilizer received additional $\mathrm{P}$ as triple superphosphate (0-20-0) and additional $\mathrm{K}$ as $\mathrm{KCl}(0-0-51)$ the following spring so that all plots received the same amounts of $\mathrm{P}$ and $\mathrm{K}$. The site was maintained as a home lawn. Plots were mowed weekly during the growing season to a height of $4.5 \mathrm{~cm}$ and clippings remained on the plots. Plots were irrigated at a rate of $2.5 \mathrm{~cm} \mathrm{wk}^{-1}$ from May to September in addition to receiving natural precipitation. Irrigation was halted for the season before the 15 September application date to minimize confounding the treatment effects with irrigation. Dolomitic limestone was applied two times during the study at $2430 \mathrm{~kg}$ $\mathrm{CaCO}_{3}$ equivalent ha ${ }^{-1}$ each to maintain a $\mathrm{pH}$ of 6.0 or higher. Any weeds were removed by hand, and plots were sprayed in September 2002 with the broadleaf selective herbicide 2,4-D (2,4-dichlorophenoxyacetic acid).

\section{Percolate Collection and Turf Color and Growth}

Beginning 7 Aug. 2000, percolate volumes in the collection vessels were measured weekly and a subsample of the percolate was removed by peristaltic pump. The remaining percolate water in each collection vessel was then removed and discarded. The percolate samples were fixed with $\mathrm{H}_{2} \mathrm{SO}_{4}$ and stored at $4^{\circ} \mathrm{C}$ for up to $28 \mathrm{~d}$. Samples were analyzed for $\mathrm{NO}_{3}-\mathrm{N}$ on a Scientific Instruments continuous flow analyzer (WESTCO, Danbury, CT) using the Griess-Ilosvay method (Keeney and Nelson, 1982). When concentrations were below the nominal detection limit of $0.05 \mathrm{mg} \mathrm{L}^{-1}$, a value of half the detection limit was recorded. This was appropriate because the frequency of samples with concentrations below the detection limit was $3.2 \%$ of total samples (USEPA, 1998). Percolate sampling was performed until 15 May 2003.

Hue, lightness, and chroma measurements of leaf blades were taken from March to November in 2001 and 2002 and from March to May 2003. For each measurement, leaf blades were clipped from a small section of a plot and laid flat in an 
optically dense stack. A color measurement was taken using a Minolta CR200b chroma meter (Konica Minolta Holding, Tokyo, Japan) in Commission Internationale de l' Eclairage (CIE) L* $\mathrm{a}^{*} \mathrm{~b} *$ coordinates at illuminant condition $\mathrm{C}$ (Hunter, 1975). The leaf blades were then randomly rearranged in the stack and another color measurement was taken. This was repeated for four measurements for each plot. Values of $\mathrm{L}^{*}, \mathrm{a}^{*}$, and $b^{*}$ were averaged per plot and converted to hue, lightness, and chroma values (McGuire, 1992).

Chlorophyll concentration measurements in leaf tissue were taken from March to November in 2001 and 2002 and from March to May 2003. For each measurement, leaf blades from a small section of a plot were clipped and collected. Chlorophyll extraction was performed using intact, fresh leaf tissue and $\mathrm{N}, \mathrm{N}$-dimethylformamide. Extracts were measured spectrophotometrically at 647 and $664.5 \mathrm{~nm}$ and chlorophyll concentration was calculated (Inskeep and Bloom, 1985).

Reflectance index measurements with the Spectrum Field Scout CM1000 chlorophyll meter (Spectrum Technologies, Plainfield, IL) were taken from September to December in 2001 and from March to November in 2002 and from March to May 2003. Ten measurements were taken and averaged per plot. All measurements were taken in full sun between 1100 and $1300 \mathrm{~h}$ with the meter facing away from the sun. Measurements were taken with the meter approximately $1.5 \mathrm{~m}$ from the turf canopy. Clipping yield measurements were taken from April to October in 2001 and 2002 and from March to May 2003. Leaf blades were clipped from a $470-\mathrm{cm}^{2}$ area of a plot, dried at $71^{\circ} \mathrm{C}$, and weighed. Measurements for hue, lightness, chroma, chlorophyll concentration, reflectance index, and clipping yield were taken at least monthly throughout the experiment. Additionally, these measurements were taken each week from March to 10 May 2002 and every 2 wk in from March to May 2003. The increased frequency of these measurements in the spring of 2002 and 2003 gave increased statistical weight to spring measurements in statistical analyses.

Shoot density measurements were taken on 30 Apr. 2002 and 29 Apr. 2003. This was done after the first mowing in the spring. Tillers were counted within two $26-\mathrm{cm}^{2}$ areas per plot and averaged. Root plus rhizome mass measurements were taken 19 Apr. 2002 and 15 Apr. 2003. This was done after spring green-up but before vigorous top growth. Two plugs measuring 2 by 11 by $17 \mathrm{~cm}$ deep were taken per plot, in a section of each plot away from lysimeters. Thatch and verdure were cut away and soil was removed by washing. The resultant root and rhizome samples were dried at $71^{\circ} \mathrm{C}$, weighed, ashed at $375^{\circ} \mathrm{C}$ for $16 \mathrm{~h}$, and weighed again. The root and rhizome mass was calculated as dry mass minus ashed mass.

\section{Statistical Analysis}

Because initial high $\mathrm{NO}_{3}-\mathrm{N}$ concentrations in percolate may have been due to mineralization stimulated by soil disturbance during establishment, the period from 1 Aug. 2000 to 14 May 2001 was considered an establishment period and was excluded from all subsequent analyses for $\mathrm{NO}_{3}-\mathrm{N}$ concentrations and mass. The experimental period was then from 15 May 2001 to 14 May 2003. All hue, lightness, chlorophyll concentration, and clipping yield measurements beginning in March 2001 were retained for subsequent analyses.

Percolate $\mathrm{NO}_{3}-\mathrm{N}$ concentration data were pooled from 15 May 2001 to 14 May 2003. Because data were positively skewed, a $\log _{10}$ transformation was applied so that data conformed to the normality of residuals assumption of parametric analysis, and the data were subjected to analysis of variance (ANOVA). Treatment means were separated with Tukey's Honestly Significant Difference test $(\alpha=0.05)$ with Kramer's adjustment for unequal treatment observations. Mass of $\mathrm{NO}_{3}-\mathrm{N}$ in percolate water was summed for each lysimeter for the period from 15 May 2001 to 14 May 2003, and the data were subject to ANOVA. Because ANOVA single-degree-offreedom contrast indicated a significant $(p=0.044)$ linear relationship across fall-fertilized treatments, a linear regression analysis was performed on yearly mean $\mathrm{NO}_{3}-\mathrm{N}$ mass loss versus date of application. Clipping yield, chlorophyll concentration, hue, lightness, chroma, and reflectance index measurements were analyzed on data pooled across all sample dates with ANOVA repeated measures analyses, with sample date as the repeated measure. Treatment means were separated according to the least significant difference test with TukeyKramer adjustment $(\alpha=0.05)$. Shoot density and root mass data were subjected to ANOVA separately for each year and to single degree-of-freedom contrasts to separate the means of fall fertilized treatments from that of the control.

Because temperature and precipitation were noticeably different across the two years of percolate sampling, and to emphasize the relationship between weather and $\mathrm{N}$ leaching losses, the percolate sampling period was divided into two years: 15 May 2001 to 14 May 2002 (designated Year 1) and 15 May 2002 to 14 May 2003 (Year 2). Percent of applied fall N collected in percolate water was calculated for each year and for both years, and differences between years within treatments were determined with ANOVA. Percent loss was calculated as (mean $\mathrm{N}$ in percolate for treatment - mean $\mathrm{N}$ in percolate for control) $/($ fall $\mathrm{N}$ applied $) \times 100 \%$.

All analyses were performed with the Statistical Analysis Software package (SAS Institute, 1999). All models were checked for homogeneity of variance, normality of residuals, and independence of residuals (Montgomery, 1997).

\section{RESULTS AND DISCUSSION}

\section{Air Temperature, Precipitation, and Percolation}

Total precipitation for Year 1 was $946 \mathrm{~mm}$, or $28 \%$ below the 30-yr normal for Storrs, CT, from 1970-1999 (Fig. 2a), and total precipitation for the winter of Year 1 (November 2001 through March 2002) was $296 \mathrm{~mm}$, or $46 \%$ below normal. Total precipitation for Year 2 was $1293 \mathrm{~mm}$, or $1 \%$ below normal, and total precipitation for the winter of Year 2 (November 2002 through March 2003 ) was $552 \mathrm{~mm}$, or $1 \%$ above normal. These values do not include added irrigation. The overall mean temperature during the winter of Year 1 was $3.4^{\circ} \mathrm{C}$, or $3.5^{\circ}$ above normal (Fig. 2b). The overall mean temperature during the winter of Year 2 was $-1.3^{\circ} \mathrm{C}$, or $1.2^{\circ}$ below normal. These observations indicate that the winter of Year 1 was drier and warmer than normal, while the winter of Year 2 was near normal.

Total precipitation across both years was $2239 \mathrm{~mm}$ and total irrigation applied across both years was $978 \mathrm{~mm}$. Total mean percolation across both years across all treatments was $1301 \mathrm{~mm}$ or $40.4 \%$ of applied irrigation and precipitation. Analysis of variance indicated no significant $(p>0.05)$ differences in percolation volumes or percents among treatments. These percolation results are similar to those of a study in Rhode Island that reported $37.2 \%$ of total irrigation and precipitation collected as percolate from a $90 \%$ Kentucky bluegrass lawn receiving scheduled irrigation, and reported no differences in percolate volumes among $\mathrm{N}$ application treatments (Morton et al., 1988). 

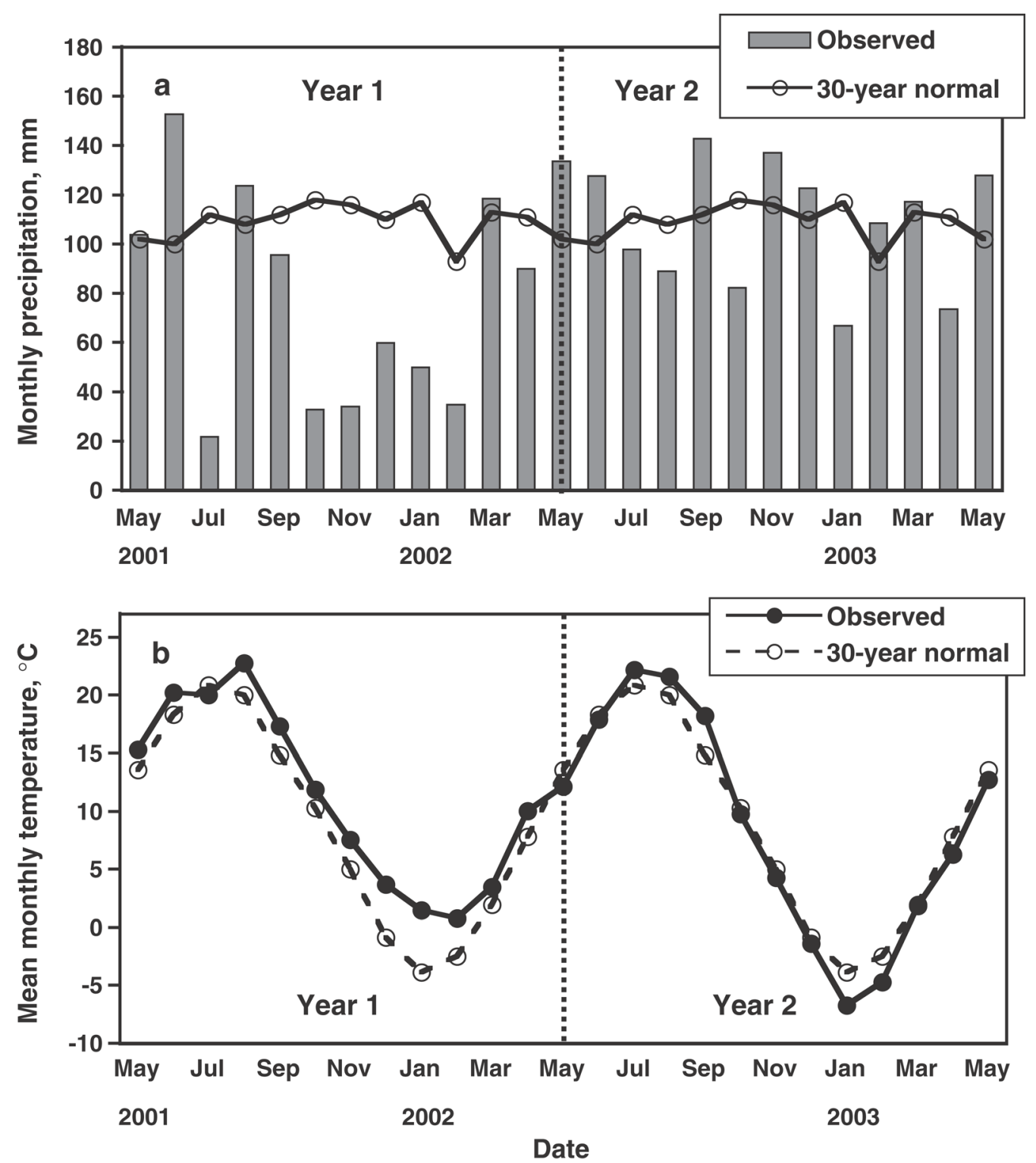

Fig. 2. Monthly precipitation with 30-yr normal precipitation (a), and mean monthly temperatures with 30-yr normal mean monthly temperatures (b), collected at Storrs, CT, USA.

\section{Percolate Nitrate Nitrogen Concentration}

Concentrations of $\mathrm{NO}_{3}-\mathrm{N}$ in percolate water of greater than $40 \mathrm{mg} \mathrm{L}^{-1}$ were observed during the establishment period (data not shown). These initial high concentrations may have been due to mineralization stimulated by soil disturbance during establishment. Geron et al. (1993) found similarly high $\mathrm{NO}_{3}-\mathrm{N}$ concentrations after establishment of a Kentucky bluegrass turf over soil monolith lysimeters. During the experimental period, concentrations varied considerably with time (Fig. 3). There was an evident elevation in $\mathrm{NO}_{3}-\mathrm{N}$ concentrations for all treatments from October 2002 to January 2003 and from January to March 2002 for the 15 September, 15 November, and 15 December treatments. This supports observations from Geron et al. (1993), Liu et al. (1997), and Guillard and Kopp (2004), who reported increased $\mathrm{NO}_{3}-\mathrm{N}$ concentrations in percolate or soil water during winter or fall. This trend was less evident in January to March 2002, which may be attributable to drier and warmer conditions during that winter.

Significant differences $(p<0.05)$ in mean $\log _{10} \mathrm{NO}_{3}-\mathrm{N}$ concentrations were found among treatments (Fig. 4). Fall fertilized treatments had significantly higher $\log _{10}$ means than did the control. Additionally, the 15 December treatment had a significantly higher mean $\log _{10}$ concentration than did the 15 September treatment.

\section{Nitrate Nitrogen Mass Collected in Percolate Water}

Cumulative $\mathrm{NO}_{3}-\mathrm{N}$ mass collected in percolate water increased moderately for the first year of the experimental period (Fig. 5). Cumulative mass increased more sharply, however, from November 2002 through February 2003. This higher mass export coincides with 


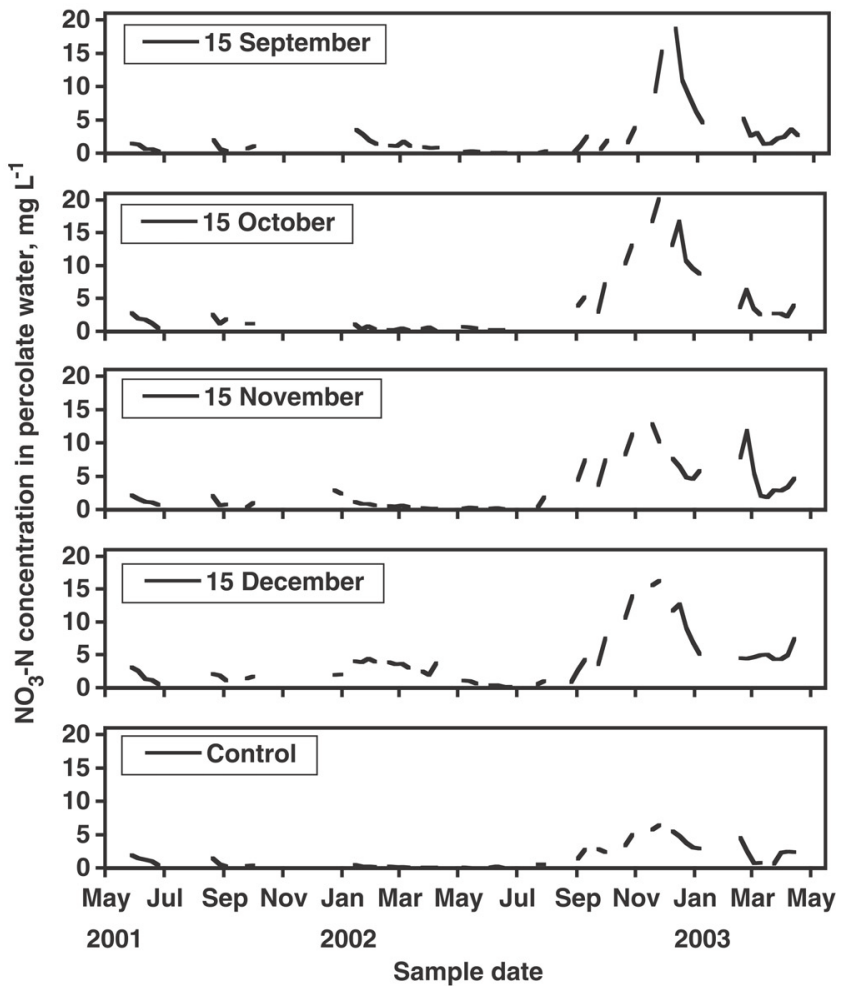

Fig. 3. Mean concentrations of $\mathrm{NO}_{3}-\mathrm{N}$ in percolate water collected under turfgrass plots in Connecticut from 15 May 2001 to 14 May 2003. Treatments are date of fall fertilization: 15 September, 15 October, 15 November, 15 December, or control (no fall fertilizer).

higher $\mathrm{NO}_{3}-\mathrm{N}$ concentrations in percolate during this period (Fig. 3), as well as with colder air temperatures and higher precipitation compared to the previous winter (Fig. 2). Because this period of increased loss was evident in all treatments in November 2002, including those not yet fertilized in the fall of that year (the

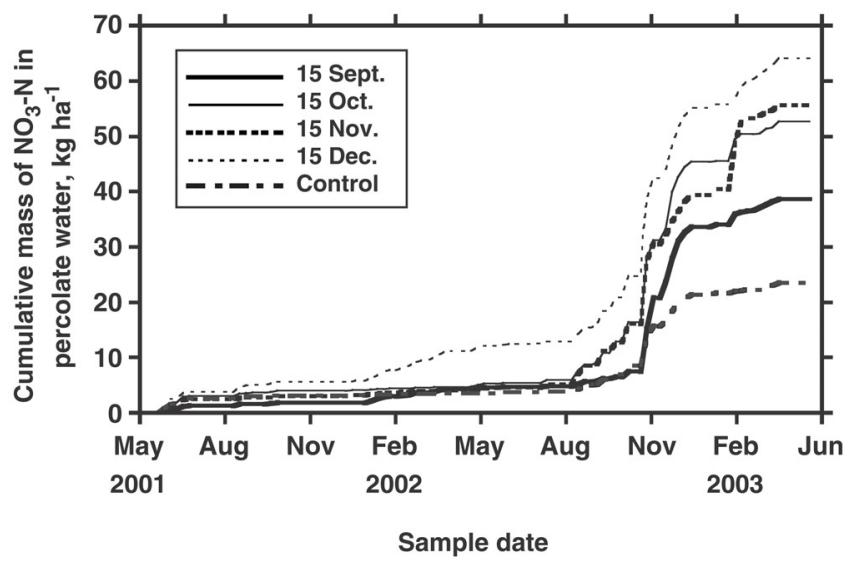

Fig. 5. Mean cumulative mass of $\mathrm{NO}_{3}-\mathrm{N}$ in percolate water collected under turfgrass plots in Connecticut across two years. Treatments are date of fall fertilization: 15 September, 15 October, 15 November, or 15 December, or control (no fall fertilizer).

15 November, 15 December, and control treatments), these losses are probably not directly related to fall applied at that time, but to residual $\mathrm{NO}_{3}-\mathrm{N}$ from previous applications or mineralization. Balkcom et al. (2003) found the timing and amount of rainfall to be major factors determining $\mathrm{NO}_{3}-\mathrm{N}$ losses from the rooting zone of corn (Zea mays L.) fields in Iowa across years. Mean cumulative $\mathrm{NO}_{3}-\mathrm{N}$ mass collected in percolate water was significantly $\left(p=0.033, r^{2}=0.94\right)$ linearly related to the date of fall fertilization (Fig. 6). The later the date of the application of fall fertilization, the more $\mathrm{NO}_{3}-\mathrm{N}$ was collected in the percolate water.

The percent of fall applied $\mathrm{N}$ collected as $\mathrm{NO}_{3}-\mathrm{N}$ in percolate water varied by year, with greater losses of fall applied $\mathrm{N}$ in Year 2 for all treatments (Table 1). The lower losses for Year 1 may be related to the lower precipitation in the winter of that year and the warmer

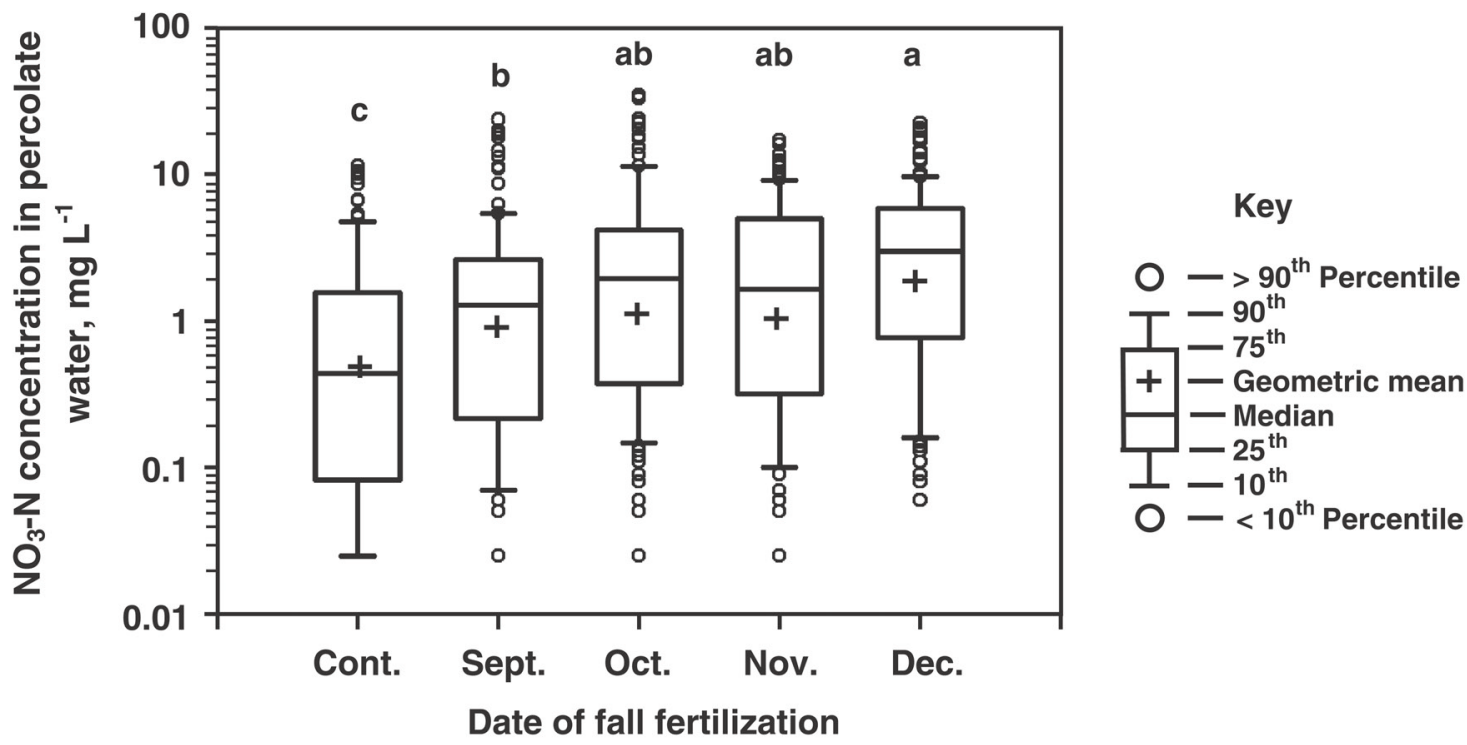

Fig. 4. Box-and-whiskers plots of non-flow-weighted $\mathrm{NO}_{3}-\mathrm{N}$ concentration observed in percolate water below turfgrass plots in Connecticut from 15 May 2001 to 14 May 2003. Treatments are date of fall fertilization: control (no fall fertilizer), 15 September, 15 October, 15 November, or 15 December. Analysis of variance indicates differences in mean $\log _{10}$ concentration among treatments $\left(p<\mathbf{0 . 0 0 0 1}\right.$ ). Same letters indicate $\log _{10}$ mean concentration not significantly different according to Tukey's Honestly Significant Difference test with Kramer's adjustment $(\alpha=0.05)$. 


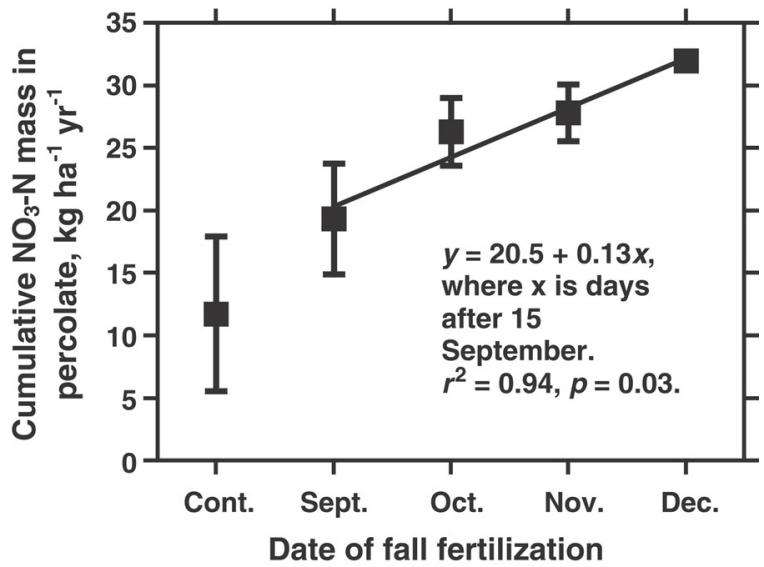

Fig. 6. Yearly mean cumulative mass of $\mathrm{NO}_{3}-\mathrm{N}$ in percolate water collected below turfgrass plots in Connecticut from 15 May 2001 to 14 May 2003. Treatments are date of fall fertilization: control (no fall fertilizer), 15 September, 15 October, 15 November, or 15 December. A linear regression relating mean $\mathrm{NO}_{3}-\mathrm{N}$ mass collected in percolate water to the date of fertilizer application is shown. Error bars indicate standard error of the mean.

temperatures during that fall which might have allowed greater plant uptake in the fall.

\section{Turf Color, Chlorophyll, and Yield}

Significant differences $(p<0.05)$ were found among treatments for least-square means from repeated measures analyses for turf hue, lightness, chlorophyll concentration, reflectance index, and clipping yield (Fig. 7). Overall, the 15 October, 15 November, and 15 December treatments were among treatments that produced the highest means for hue, chlorophyll concentration, and clipping yield, and among the lowest for lightness. A higher hue implies a greener color; a higher chroma implies a more saturated color; a lower lightness implies a darker color. These repeated measures analyses included measurements from throughout the growing season. However, because these measurements represented three spring seasons and measurements were taken more frequently during the spring, they were heavily weighted in favor of spring measurements (February through May). Because spring color and growth is of concern following fall fertilization, this weighting was considered desirable.

In general, these color and growth results agree with other studies in that fall fertilization tended to improve spring turf color or quality (Powell et al., 1967b; Wilkinson and Duff, 1972; Wehner et al., 1988; Wehner and Haley, 1993; Oral and Acikgoz, 2001). However, these results differ from results of Wehner and Haley (1993), in Illinois, who found higher spring color ratings in turf fertilized later in the fall than in October. Similarly, Wilkinson and Duff (1972), in Rhode Island, found greater spring chlorophyll in mid-April in turf fertilized in November or December than in October. Differences among results from these two studies and the present study may have resulted from differences in climate, soil, or Kentucky bluegrass variety.
Table 1. Percent of applied fall fertilizer $\mathrm{N}$ collected as $\mathrm{NO}_{3}-\mathrm{N}$ in percolate water from turfgrass in Connecticut over two years. Treatment is date of fall fertilizer application. Year 1 is 15 May 2001 to 14 May 2002. Year 2 is 15 May 2002 to 14 May 2003. Analysis of variance indicates percent mass collected in percolate is different between Year 1 and Year 2 for each treatment $(p<0.05)$. Year 1 was characterized by a winter that was warmer and drier than normal.

\begin{tabular}{lccc}
\hline & \multicolumn{3}{c}{ Applied fall N mass collected in percolate $\dagger$} \\
\cline { 2 - 4 } Treatment & Year 1 & Year 2 & Both years \\
\cline { 2 - 4 } & & $\%$ & \\
15 Sept. & 2.0 & 29.1 & 15.5 \\
15 Oct. & 3.1 & 56.4 & 29.8 \\
15 Nov. & 1.6 & 64.2 & 32.9 \\
15 Dec. & 16.8 & 66.1 & 41.4 \\
\hline
\end{tabular}

$\dagger$ Percent lost $=($ mean $\mathbf{N}$ in percolate for treatment - mean $\mathbf{N}$ in percolate for control)/(fall $\mathrm{N}$ applied) $\times 100 \%$.

\section{Shoot Density and Root Mass}

In the present study, no differences were found among fall fertilized treatments for either year for shoot density or root mass (Fig. 8). Orthogonal contrasts from ANOVA indicated that fall fertilized treatments were greater $(p<0.05)$ than control for shoot density for each year, with no differences $(p>0.05)$ among fall fertilized treatments. These shoot density data differ from those of Oral and Acikgoz (2001), who found no increase in shoot density from fall fertilization. However, they presented data from Turkey, which may not be applicable to southern New England, and from turf receiving higher rates of $\mathrm{N}$. In our study, no differences $(p>0.05)$ were found among root mass means for either year (Fig. 8). In Maryland, Hanson and Juska (1961) found increased root mass with fall $\mathrm{N}$ fertilization of Kentucky bluegrass, but only over unfertilized control plots. In our study, control plots were not fertilized in fall but received spring and summer fertilization. Additionally, the data from Maryland may not be applicable to southern New England. Milder winter temperatures in Maryland may allow for greater potential for $\mathrm{N}$ uptake during late fall and winter compared with southern New England. The root mass results of our study also differ somewhat from those of Powell et al. (1967b), who found spring root mass increases with additional fall $\mathrm{N}$ applied in December and October over that applied only in October. Our study did not investigate additional $\mathrm{N}$ applications to turf already fertilized in October. Additionally, they presented data from a bentgrass (Agrostis stolonifera L.) turf and from Virginia, which may not be applicable to a Kentucky bluegrass turf in southern New England. In our study, means for both root mass and shoot density were noticeably lower in April 2003 than in April 2002 (Fig. 8). This difference may reflect the colder fall and winter preceding April 2003 than that preceding April 2002.

\section{Nitrogen Sources, Timing, and Rates}

Results from this study suggest that a considerable percentage of soluble $\mathrm{N}$ applied to turfgrass in November or December could be lost through leaching (Table 1). This percentage, however, may depend on the rate of 

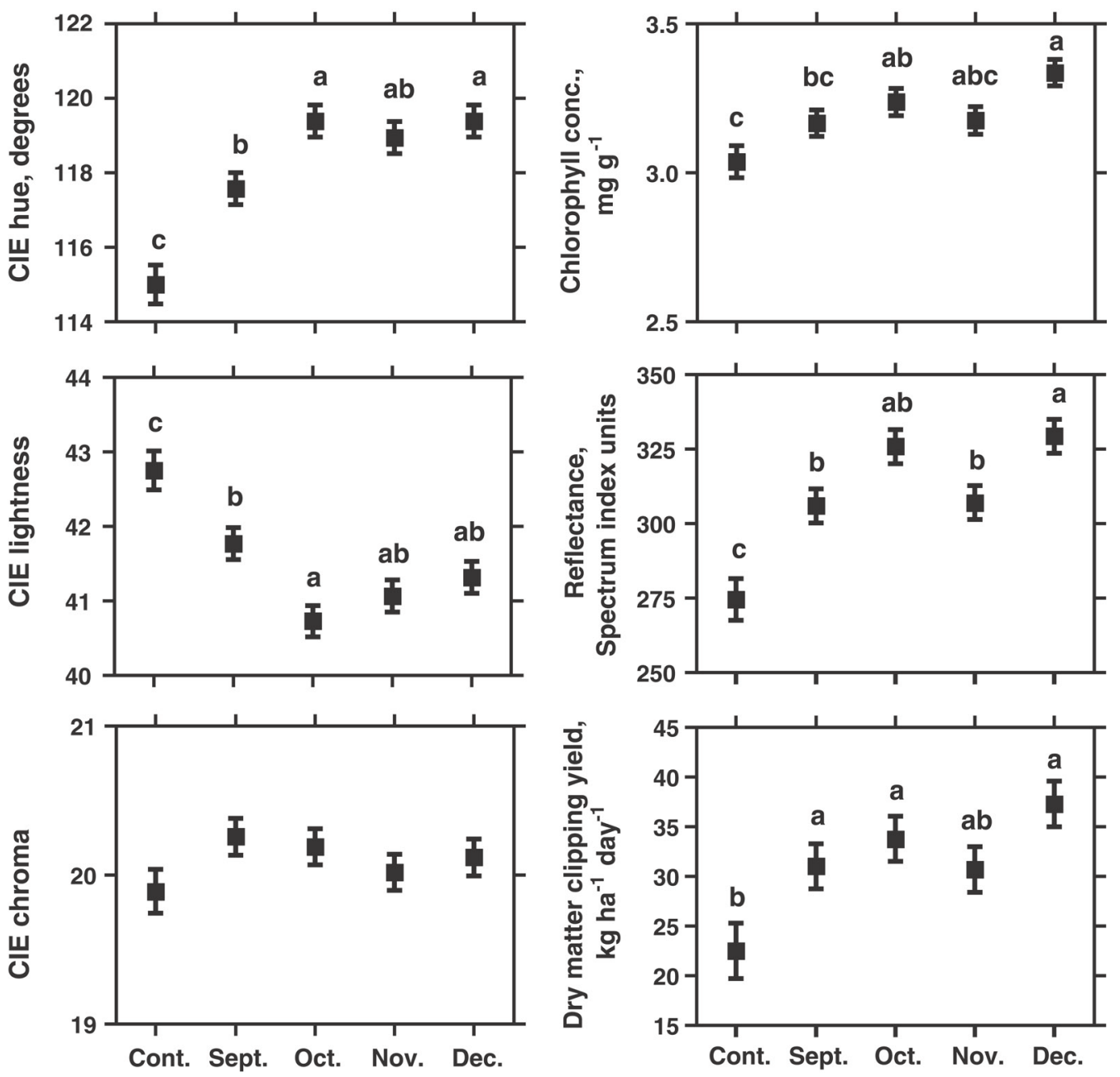

Date of fall fertilization

Fig. 7. Plots of least square (LS) means from repeated measures analyses of color measurements, reflectance index, leaf chlorophyll concentration, and clipping yield measurements from March 2001 to May 2003 on turfgrass plots. Treatments are date of fall fertilization: control (no fall fertilizer), 15 September, 15 October, 15 November, or 15 December. Error bars indicate standard error of the LS mean from repeated measures analyses. Significant differences were found among treatments for Commission Internationale de l' Eclairage (CIE) hue ( $p<0.0001)$, CIE lightness $(p<0.0001)$, chlorophyll concentration $(p=0.0003)$, reflectance index $(p<0.0001)$, and dry matter clipping yield $(p=0.0011)$. Same letters within a plot indicate means not significantly different according to least significant difference test with Tukey-Kramer adjustment $(\boldsymbol{\alpha}=\mathbf{0 . 0 5})$.

fall $\mathrm{N}$ application. A rate considerably less than the $49 \mathrm{~kg}$ $\mathrm{N} \mathrm{ha}{ }^{-1}$ used in this study for fall application may lower the percentage of applied $\mathrm{N}$ lost through leaching, and may represent a reasonable application in the late fall.

While data from this study suggested that fertilizing turf on 15 October or later with $49 \mathrm{~kg} \mathrm{~N} \mathrm{ha}^{-1}$ will improve turf color and density, optimizing turf color or density is not always a priority over water quality concerns. Data from this study suggested a negative water quality impact from fall fertilization, in that adding fall fertilizer increased mean $\mathrm{NO}_{3}-\mathrm{N}$ concentration in percolate (Fig. 4), and applying fertilizer after 15 September increased $\mathrm{NO}_{3}-\mathrm{N}$ mass in percolate water (Fig. 6). This study did not use any subjective ratings for turf quality, nor are there established values for acceptable turf with the quantitative turf measurements used in this study. However, we noted that turf color, density, and growth were acceptable for most uses throughout the year on plots receiving fall fertilizer in September or receiving no fall fertilizer. If water quality is a priority, prudence may dictate an early or low-rate fall $\mathrm{N}$ application, or no fall $\mathrm{N}$ application. Additionally, rates of fall $\mathrm{N}$ application should be adjusted downward to account for residual available soil $\mathrm{NO}_{3}-\mathrm{N}$ from previous applications and mineralization, especially if soil organic matter is substantial.

This study was conducted using fall fertilizer with water-soluble $\mathrm{N}$ sources. It is not clear how fall fertilizer recommendations for slow-release $\mathrm{N}$ sources would differ from those for soluble $\mathrm{N}$ sources. Because slow-release $\mathrm{N}$ sources may depend on moisture, temperature, and microbiological activity to become available for plant uptake or leaching, turf quality and $\mathrm{NO}_{3}-\mathrm{N}$ leaching losses may be especially sensitive to $\mathrm{N}$ source effects in fall fertilizer. Wehner and Haley (1993) found higher spring color ratings for sulfur-coated urea with applications in November and December over October, but not for Milorganite. 


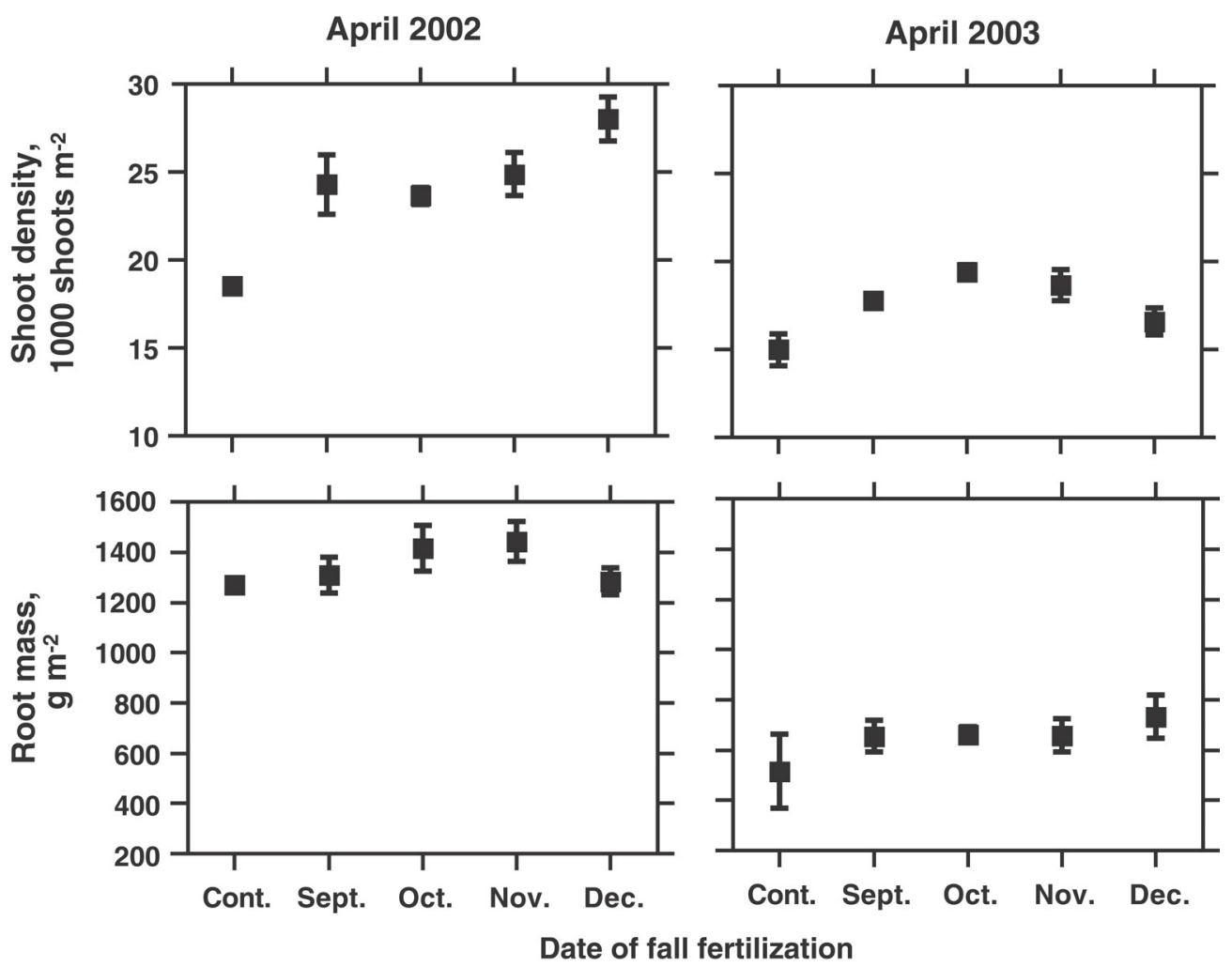

Fig. 8. Plots of means for shoot density and root plus rhizome mass during April of 2002 and 2003 on turfgrass plots in Connecticut. Treatments are date of fall fertilization: control (no fall fertilizer), 15 September, 15 October, 15 November, or 15 December. Error bars indicate standard error of the mean. Orthogonal contrasts from ANOVA indicate fall fertilized treatments greater than control for shoot density for each year $(p=$ $\mathbf{0 . 0 3 4}$ for 2002 and $p=\mathbf{0 . 0 4 9}$ for 2003 ), with no differences among fall fertilized treatments. No differences were found among root mass means for either year.

They also found, with a November application, higher spring color on more dates for sulfur-coated urea compared with urea, but not for Milorganite compared with urea. Because less $\mathrm{N}$ would be susceptible to movement by water, the use of slow-release $\mathrm{N}$ sources for fall application may reduce fall and winter $\mathrm{N}$ leaching losses from turfgrass. A few studies have found lower $\mathrm{NO}_{3}-\mathrm{N}$ leachate concentrations or losses from slow release $\mathrm{N}$ sources or organic sources applied to cool-season turf than from immediately soluble sources (Geron et al., 1993; Easton and Petrovic, 2004; Guillard and Kopp, 2004).

\section{CONCLUSIONS}

Applying fall fertilizer improved turf color and increased shoot density, chlorophyll concentration, reflectance index, and clipping yield in our cool-season turf lawn. However, no differences in color, clipping yield, chlorophyll concentration, shoot density, or root mass were found among the 15 October, 15 November, or 15 December treatments. In contrast to this, however, the data from this study suggest a potential negative impact to water quality by applying fertilizer late in the fall. Both $\mathrm{NO}_{3}-\mathrm{N}$ concentrations and mass losses in percolate water increased with later application dates. These findings suggest that the current recommendation of applying $\mathbf{N}$ in mid- to late November in southern New England may not be compatible with water quality goals. Water quality concerns would dictate an early or low- rate fall application if soluble $\mathrm{N}$ fertilizer is used, or no fall $\mathrm{N}$ application. Because $\mathrm{NO}_{3}-\mathrm{N}$ concentrations and mass losses were elevated in the fall and winter in this study, consideration of temperature, moisture, and existing available soil $\mathrm{N}$ is of particular concern when making fall fertilizer recommendations. More research addressing the interactions of the effects of timing, source, and rate is necessary before optimal application recommendations for fall fertilizer can be made with confidence. Concerns about the timing of fall-applied fertilizer are especially relevant in northern climates where cold weather and high precipitation in the fall and winter limit potential plant uptake and increase the likelihood of considerable $\mathrm{N}$ leaching losses.

\section{ACKNOWLEDGMENTS}

Funding for this research was supplied by the USDA National Research Initiative Competitive Grants Program, Award 99-35102-8598. We are grateful to Dr. Thomas F. Morris and Dr. John C. Clausen for their comments and suggestions for this paper.

\section{REFERENCES}

Balkcom, K.S., A.M. Blackmer, D.J. Hansen, T.F. Morris, and A.P. Mallarino. 2003. Testing soils and cornstalks to evaluate nitrogen management on a watershed scale. J. Environ. Qual. 32:1015-1024.

Ball, D.F. 1964. Loss-on-ignition as an estimate of organic matter and organic carbon in non-calcareous soils. J. Soil Sci. 15:84-92. 
Colangelo, D.J., and M.H. Brand. 2001. Nitrate leaching beneath a containerized nursery crop receiving trickle or overhead irrigation. J. Environ. Qual. 30:1564-1574.

Easton, Z.M., and A.M. Petrovic. 2004. Fertilizer source effect on ground and surface water quality in drainage from turfgrass. J. Environ. Qual. 33:645-655.

Geron, C.A., T.K. Danneberger, S.J. Traina, T.J. Logan, and J.R. Street. 1993. The effects of establishment methods and fertilization practices on a nitrate leaching from turfgrass. J. Environ. Qual. 22:119-125.

Guillard, K., and K.L. Kopp. 2004. Nitrogen fertilizer form and associated nitrate leaching from cool-season lawn turf. J. Environ. Qual. 33:1822-1827.

Hanson, A.A., and F.V. Juska. 1961. Winter root activity in Kentucky bluegrass (Poa pratensis L.). Agron. J. 53:372-374.

Hunter, R.S. 1975. The measurement of appearance. John Wiley \& Sons, New York.

Inskeep, W.P., and P.R. Bloom. 1985. Extinction coefficients of chlorophyll a and b in N,N-dimethylformamide and $80 \%$ acetone. Plant Physiol. 77:483-485.

Keeney, D.R., and D.W. Nelson. 1982. Nitrogen-Inorganic forms. p. 643-698. In A.L. Page et al. (ed.) Methods of soil analysis. Part 2. 2nd ed. Agron. Monogr. 9. ASA and SSSA, Madison, WI.

Liu, H., R.J. Hull, and D.T. Duff. 1997. Comparing cultivars of three cool-season turfgrasses for soil water $\mathrm{NO}_{3}{ }^{-}$concentration and leaching potential. Crop Sci. 37:526-534.

McGuire, R.G. 1992. Reporting of objective color measurements. HortScience 27:1254-1255.

Miltner, E.D., B.E. Branham, E.A. Paul, and P.E. Rieke. 1996. Leaching and mass balance of ${ }^{15} \mathrm{~N}$-labeled urea applied to a Kentucky bluegrass turf. Crop Sci. 36:1427-1433.

Miltner, E.D., G.K. Stahnke, and P.A. Backman. 2001. Leaf tissue N content and soil $\mathrm{N}$ status following monthly applications of nitrogen fertilizer to fairway turf. Int. Turfgrass Soc. Res. J. 9:409-415.
Montgomery, D.C. 1997. Design and analysis of experiments. 4th ed. John Wiley \& Sons, New York.

Morton, T.G., A.J. Gold, and W.M. Sullivan 1988. Influence of overwatering and fertilization on nitrogen losses from home lawns. J. Environ. Qual. 17:124-130.

Mulvaney, R.L. 1996. Nitrogen-Inorganic forms. p. 1123-1184. In D.L. Sparks (ed.) Methods of soil analysis. Part 3. SSSA Book Ser. 5. SSSA, Madison, WI.

Oral, N., and E. Acikgoz. 2001. Effects of nitrogen application timing on growth and quality of a turfgrass mixture. J. Plant Nutr. 24: 101-109.

Petrovic, A.M. 1990. The fate of nitrogenous fertilizers applied to turfgrass. J. Environ. Qual. 19:1-14.

Petrovic, A.M., N.W. Hummel, and M.J. Carrol. 1986. Nitrogen source effects on nitrate leaching from late fall nitrogen applied to turfgrass. p. 137. In 1986 Agronomy abstracts. ASA, Madison, WI.

Powell, A.J., R.E. Blaser, and R.E. Schmidt. 1967a. Effect of nitrogen on winter root growth of bentgrass. Agron. J. 59:529-530.

Powell, A.J., R.E. Blaser, and R.E. Schmidt. 1967b. Physiological and color aspects of turfgrasses with fall and winter nitrogen. Agron. J. 59:303-307.

SAS Institute. 1999. SAS OnlineDoc, Version 8. SAS Inst., Cary, NC.

USEPA. 1998. Guidance for data quality assessment: Practical methods for data analysis. EPA QA/G-9 QA97 Version, EPA/600/R-96/084. USEPA, Washington, DC

Wehner, D.J., and J.E. Haley. 1993. Effects of late fertilization on turfgrass as a influenced by application timing and $\mathrm{N}$ source. Int. Turfgrass Soc. Res. J. 7:580-586.

Wehner, D.J., J.E. Haley, and D.L. Martin. 1988. Late fall fertilization of Kentucky bluegrass. Agron. J. 80:466-471.

Wilkinson, J.F., and D.T. Duff. 1972. Effects of fall fertilization on cold resistance, color, and growth of Kentucky bluegrass. Agron. J. 64: 345-348. 